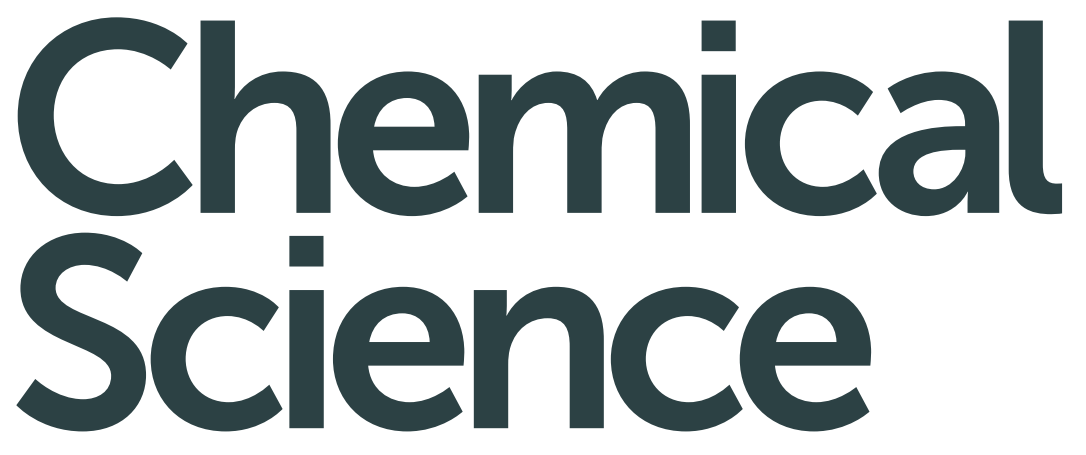

rsc.li/chemical-science

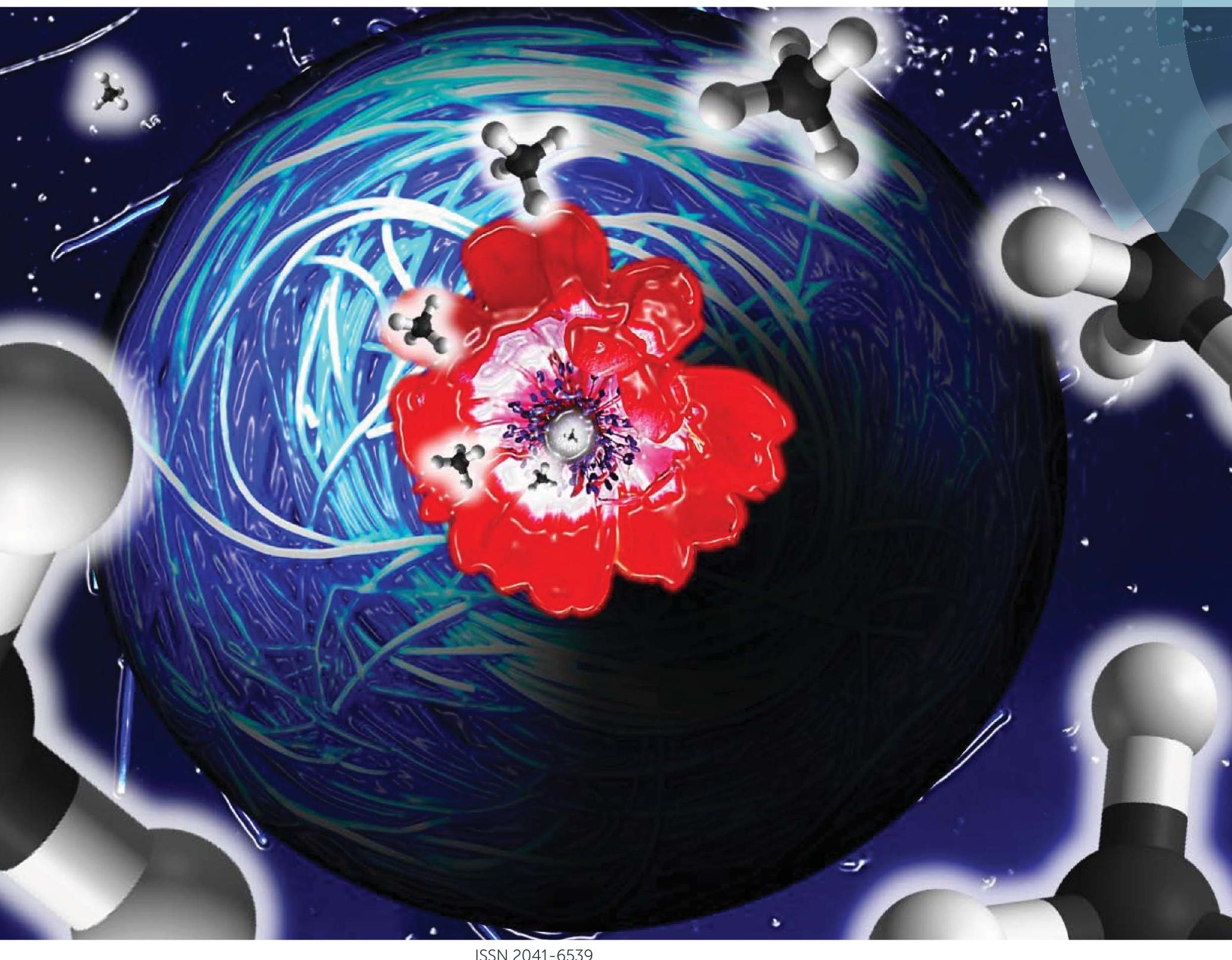

ISSN 2041-6539

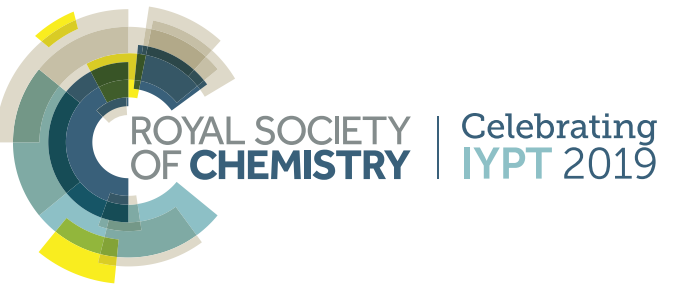

EDGE ARTICLE

Xiaobo Peng, Takeshi Fujita, Hideki Abe et al.

Topologically immobilized catalysis centre for long-term

stable carbon dioxide reforming of methane 
Check for updates

Cite this: Chem. Sci., 2019, 10, 3701

๑ All publication charges for this article have been paid for by the Royal Society of Chemistry

Received 7th November 2018

Accepted 12th February 2019

DOI: $10.1039 / \mathrm{c} 8 \mathrm{sc} 04965 \mathrm{c}$

rsc.li/chemical-science

\section{Topologically immobilized catalysis centre for long-term stable carbon dioxide reforming of methane $\uparrow$}

\author{
Shusaku Shoji, ${ }^{a}$ Xiaobo Peng, (D) *b Tsubasa Imai, ${ }^{c}$ Paskalis Sahaya Murphin Kumar, (D) d \\ Kimitaka Higuchi, ${ }^{e}$ Yuta Yamamoto, ${ }^{e}$ Tomoharu Tokunaga, ${ }^{e}$ Shigeo Arai, \\ Shigenori Ueda, ${ }^{\text {bf }}$ Ayako Hashimoto, ${ }^{\text {bg }}$ Noritatsu Tsubaki, (D) ${ }^{\mathrm{h}}$ Masahiro Miyauchi, (D) a \\ Takeshi Fujita (D)*i and Hideki Abe (D) *bc
}

Methane reforming at low temperatures is of growing importance to mitigate the environmental impact of the production of synthesis gas, but it suffers from short catalyst lifetimes due to the severe deposition of carbon byproducts. Herein, we introduce a new class of topology-tailored catalyst in which tens-ofnanometer-thick fibrous networks of $\mathrm{Ni}$ metal and oxygen-deficient $\mathrm{Y}_{2} \mathrm{O}_{3}$ are entangled with each other to form a rooted structure, i.e., $\mathrm{Ni}_{2} \mathrm{Y}_{2} \mathrm{O}_{3}$. We demonstrate that the rooted $\mathrm{Ni}_{2} \mathrm{Y}_{2} \mathrm{O}_{3}$ catalyst stably promotes the carbon-dioxide reforming of methane at $723 \mathrm{~K}$ for over $1000 \mathrm{~h}$, where the performance of traditional supported catalysts such as $\mathrm{Ni} / \mathrm{Y}_{2} \mathrm{O}_{3}$ diminishes within $100 \mathrm{~h}$ due to the precluded mass transport by accumulated carbon byproducts. In situ TEM demonstrates that the supported $\mathrm{Ni}$ nanoparticles are readily detached from the support surface in the reaction atmosphere, and migrate around to result in widespread accumulation of the carbon byproducts. The long-term stable methane reforming over the rooted catalyst is ultimately attributed to the topologically immobilized $\mathrm{Ni}$ catalysis centre and the synergistic function of the oxygen-deficient $\mathrm{Y}_{2} \mathrm{O}_{3}$ matrix, which successfully inhibits the accumulation of byproducts.

\section{Introduction}

The catalytic conversion of the major component in biogas and natural gas, methane $\left(\mathrm{CH}_{4}\right)$, into valuable synthesis gas

${ }^{a}$ Department of Materials Science and Engineering, School of Materials and Chemical Technology, Tokyo Institute of Technology, 2-12-1, Ookayama, Meguro-ku, Tokyo, 152-8552, Japan

${ }^{b}$ National Institute for Materials Science, 1-1 Namiki, Tsukuba, Ibaraki 305-004, Japan.E-mail: PENG.Xiaobo@nims.go.jp;ABE.Hideki@nims.go.jp

${ }^{c}$ Graduate School of Science and Technology, Saitama University, 255 Shimo-Okubo, Saitama 338-8570, Japan

${ }^{d}$ Anna University, Chennai, Tamil Nadu 600-025, India

'Institute of Materials and Systems for Sustainability, Nagoya University, Furo-cho, Chikusa-ku, Nagoya 464-8601, Japan

${ }^{f}$ Synchrotron X-ray Station at SPring-8, National Institute for Materials Science, 1-1-1 Kouto, Sayo, Hyogo, 679-5148, Japan

${ }^{g}$ Precursory Research for Embryonic Science and Technology, Japan Science and Technology Agency (JST), 4-1-8 Honcho, Kawaguchi, Saitama 332-0012, Japan

${ }^{h}$ Department of Applied Chemistry, School of Engineering, University of Toyama, 3190 Gofuku, Toyama 930-8555, Japan

${ }^{i}$ School of Environmental Science and Engineering, Kochi University of Technology, 185 Miyanokuchi, Tosayamada, Kami City, Kochi 782-8502, Japan. E-mail: fujita. takeshi@kochi-tech.ac.jp

$\dagger$ Electronic supplementary information (ESI) available: Demonstration procedure; experimental and characterization details. See DOI: $10.1039 / \mathrm{c} 8 \mathrm{sc} 04965 \mathrm{c}$ consisting of $\mathrm{CO}$ and $\mathrm{H}_{2}$, is of increasing importance to establish a hydrogen-based society as well as for petroleum-free carbon resource management. Meanwhile, it is acknowledged that deposition of solid-state carbon byproducts (carbon deposition) is a significant drawback for $\mathrm{CH}_{4}$ reforming. ${ }^{1-9}$ In order to suppress carbon deposition, $\mathrm{CH}_{4}$ reforming is currently conducted at high temperatures $(>1073 \mathrm{~K})$ and as a result, suffers from rapid catalyst degradation and huge energy consumption. ${ }^{1-4}$ In contrast, $\mathrm{CH}_{4}$ reforming at $873 \mathrm{~K}$ or lower temperatures may be favourable to mitigate the catalyst degradation and environmental impacts. However, the carbon deposition is strongly accelerated at low temperatures via $\mathrm{CH}_{4}$ decomposition $\left(\mathrm{CH}_{4}=\mathrm{C}(\mathrm{s})+2 \mathrm{H}_{2}\right)$ and/or CO disproportionation $\left(2 \mathrm{CO}=\mathrm{C}(\mathrm{s})+\mathrm{CO}_{2}\right)$, which inhibits mass transport and shortens catalyst lifetime. ${ }^{1,7-9}$ Although $\mathrm{CO}_{2}$ dry reforming of $\mathrm{CH}_{4}$ (DRM: $\mathrm{CH}_{4}+\mathrm{CO}_{2}=2 \mathrm{CO}+2 \mathrm{H}_{2}$ ) is highly promising among the different types of $\mathrm{CH}_{4}$ reforming in terms of the efficient use of carbon feedstocks and the reduction of $\mathrm{CO}_{2}$ emissions, ${ }^{1,10-18}$ DRM is the most readily subjected to carbon deposition, especially at low temperatures. Recently, several strategies of designing core-shell structures and/or doping with other additive elements have been proposed to suppress undesirable carbon deposition, ${ }^{19-29}$ yet it still remains a challenge.

Herein, we propose a material design strategy to preclude carbon deposition via tailoring the three-dimensional topology 
of metal/oxide nanocomposites. We demonstrate that a nanocomposite, consisting of entangled networks of tens-ofnanometre-thick fibrous phases of nickel metal and oxygendeficient yttrium oxide, i.e., $\mathrm{Ni}_{\mathrm{H}} \mathrm{Y}_{2} \mathrm{O}_{3}$, can be prepared by utilizing nanophase-separation of a $\mathrm{Ni}-\mathrm{Y}$ alloy in an oxidative atmosphere. The $\mathrm{Ni} \# \mathrm{Y}_{2} \mathrm{O}_{3}$ catalyst can activate $\mathrm{CO}_{2}$ and $\mathrm{CH}_{4}$ from a low temperature of $623 \mathrm{~K}$ (see Fig. S1 $\dagger$ ) and stably promote the DRM reaction at $723 \mathrm{~K}$ (low-temperature DRM; abbreviated as LT-DRM hereafter) for over $1000 \mathrm{~h}$, whereas traditional supported catalysts such as $\mathrm{Ni} / \mathrm{Al}_{2} \mathrm{O}_{3}$ and $\mathrm{Ni} / \mathrm{Y}_{2} \mathrm{O}_{3}$ diminish the catalytic performance within $100 \mathrm{~h}$. Advanced characterizations, including in situ transmission electron microscopy, elucidate that particle migration occurs in the supported catalysts in the reaction atmosphere, and the migrating metal nanoparticles act as a major catalyst centre for the widespread growth of fibrous carbon byproducts. However, the $\mathrm{Ni}$ catalysis centre of the $\mathrm{Ni} \# \mathrm{Y}_{2} \mathrm{O}_{3}$ catalyst is, like a tree deeply rooted in the ground, topologically immobilized by entanglement with the oxygen-deficient $\mathrm{Y}_{2} \mathrm{O}_{3}$ matrix, which can eliminate carbon byproducts to realize long-term stable DRM performance.

\section{Results and discussion}

The preparation processes for different metal/oxide catalysts are shown in Fig. 1. Traditional supported catalysts including Ni/ $\mathrm{Y}_{2} \mathrm{O}_{3}$ and $\mathrm{Ni} / \mathrm{Al}_{2} \mathrm{O}_{3}$ were prepared by a routine impregnation method (Fig. 1a; see the ESI $\dagger$ for details). The $\mathrm{Ni} \# \mathrm{Y}_{2} \mathrm{O}_{3}$ catalyst was obtained from a Ni-Y (Ni : Y = 1:1) alloy precursor consisting of Ni metal and oxyphilic Y metal (Fig. S2 $\dagger$ ). The Ni-Y alloy was heated at $873 \mathrm{~K}$ in a gas mixture of $\mathrm{CO}$ and $\mathrm{O}_{2}$ ( $\mathrm{CO}: \mathrm{O}_{2}=2: 1$ in volume $\%$; see details in the ESI $\dagger$ ) to promote nanophase separation from a uniform alloy into a nanocomposite consisting of metal $\mathrm{Ni}$ and $\mathrm{Y}_{2} \mathrm{O}_{3}$, namely, $\mathrm{Ni} \# \mathrm{Y}_{2} \mathrm{O}_{3}$.

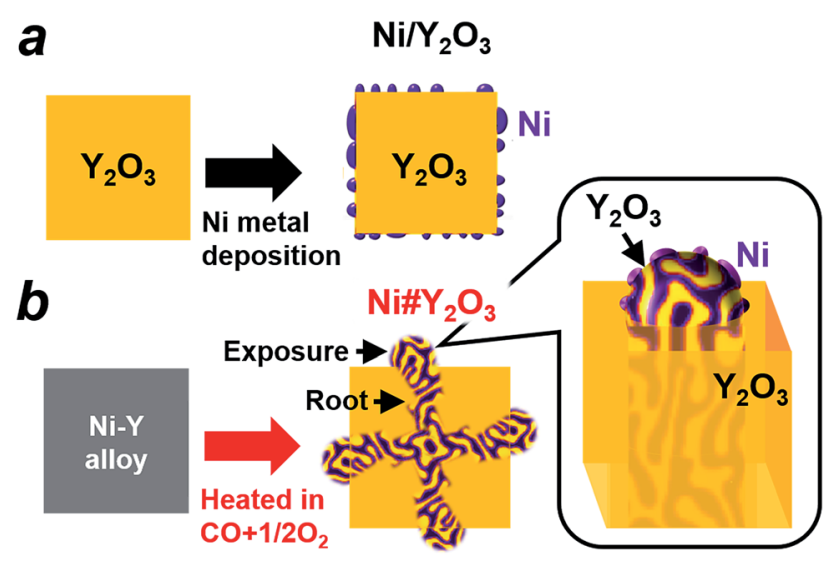

Fig. 1 Designing metal/oxide catalysts with different topologies. (a) Traditional supported catalysts such as $\mathrm{Ni} / \mathrm{Y}_{2} \mathrm{O}_{3}$ are prepared by depositing Ni nanoparticles onto the support surface. (b) The rooted $\mathrm{Ni \# Y_{2 }} \mathrm{O}_{3}$ catalyst is prepared by (1) melting $\mathrm{Ni}$ and $\mathrm{Y}$ metals into a Ni-Y alloy in an Ar atmosphere and then (2) heating the prepared $\mathrm{Ni}-\mathrm{Y}$ alloy in an atmosphere consisting of $\mathrm{CO}$ and $\mathrm{O}_{2}$. A fibrous $\mathrm{Ni}$ phase is entangled with the $\mathrm{Y}_{2} \mathrm{O}_{3}$ counterpart and further rooted in the bulk (see the inset).
The Ni\# $\mathrm{Y}_{2} \mathrm{O}_{3}$ nanocomposite comprised an entangled network of fibrous metal Ni and $\mathrm{Y}_{2} \mathrm{O}_{3}$, which further sprouted out of the bulk to develop a rooted structure (Fig. 1b; see Fig. S3† for a possible formation mechanism of the rooted structure). ${ }^{30}$ As the control catalyst, different $\mathrm{Ni}-\mathrm{Y}_{2} \mathrm{O}_{3}$ nanocomposites with different $\mathrm{Ni} / \mathrm{Y}$ ratios of $5 / 1,3 / 1,2 / 1$ and $1 / 3$ were prepared from the corresponding $\mathrm{Ni}-\mathrm{Y}$ alloy precursors $\left(\mathrm{Ni}_{5} \mathrm{Y}, \mathrm{Ni}_{3} \mathrm{Y}, \mathrm{Ni}_{2} \mathrm{Y}\right.$ and $\mathrm{NiY}_{3}$, respectively; Fig. S4 and $\left.\mathrm{S} 5 \dagger\right)$ via the same atmospheric treatment as for the $\mathrm{Ni} \# \mathrm{Y}_{2} \mathrm{O}_{3}$.

The microstructure of the $\mathrm{Ni}_{2} \mathrm{Y}_{2} \mathrm{O}_{3}$ catalyst was characterized with a scanning electron microscope (SEM). A number of precipitates were observed on the surface of the $\mathrm{Ni}_{2} \mathrm{Y}_{2} \mathrm{O}_{3}$ particles (Fig. 2a). The cross-section SEM images demonstrated that the precipitates arose from the exposure of a rooted structure that propagated from the bulk to the surface (Fig. 2b). High-magnification SEM and STEM observations further showed that the rooted structure was composed of fibrous Niand $\mathrm{Y}_{2} \mathrm{O}_{3}$ phases (Fig. 2c and d, see also Fig. $1 \mathrm{~b}$ and $\mathrm{S} 6-\mathrm{S} 8 \dagger$ ).

We tested the $\mathrm{Ni} \# \mathrm{Y}_{2} \mathrm{O}_{3}$ catalyst for LT-DRM in comparison to the other Ni-based catalysts prepared from different alloy precursors (Fig. 3a, see the corresponding SEM images in Fig. S5 $\dagger$ ). Pure Ni-powder exhibited very low activity, due to the low dispersion degree of the active $\mathrm{Ni}$ sites (Table $\mathrm{S} 1$ and Fig. S9 $\dagger$ ). The different $\mathrm{Ni}-\mathrm{Y}_{2} \mathrm{O}_{3}$ composites also exhibited lower consumption- and formation rates than the $\mathrm{Ni} \# \mathrm{Y}_{2} \mathrm{O}_{3}$ catalyst. This should be attributed to the overgrowth of $\mathrm{Ni}$ or $\mathrm{Y}_{2} \mathrm{O}_{3}$ during the atmospheric processing of $\mathrm{CO} / \mathrm{O}_{2}$ (Fig. S5 and $\mathrm{S} 9 \dagger$ ). The $\mathrm{CH}_{4}$ - and $\mathrm{CO}_{2}$ consumption rates over the $\mathrm{Ni} \# \mathrm{Y}_{2} \mathrm{O}_{3}$ catalyst were close to half the value of the $\mathrm{CO}$ - and $\mathrm{H}_{2}$ formation rates, showing that the LT-DRM was promoted in a nearly stoichiometric pathway. We then evaluated the turnover frequency (TOF) of $\mathrm{Ni \# Y}_{2} \mathrm{O}_{3}$ and the different Ni-based catalysts towards $\mathrm{CH}_{4}$ conversion (i.e. $\mathrm{TOF}_{\mathrm{CH}_{4}}$, Table $\mathrm{S} 2 \dagger$ ). ${ }^{31,32}$ The $\mathrm{Ni}_{2} \mathrm{Y}_{2} \mathrm{O}_{3}$

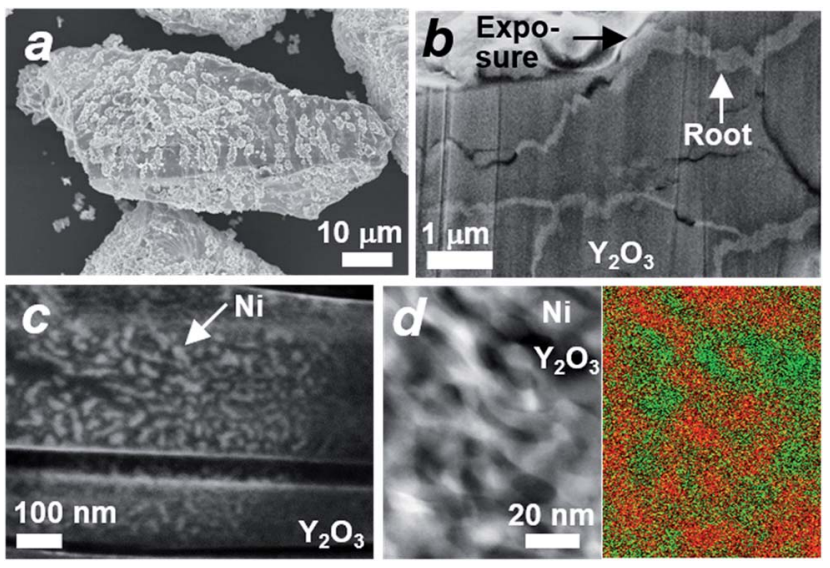

Fig. 2 Micro- and nanostructures of the rooted catalysts. (a) SEM image of one of the $\mathrm{Ni}_{2} \mathrm{Y}_{2} \mathrm{O}_{3}$ particles. (b) Cross-section SEM image of one of the $\mathrm{Ni \# Y}_{2} \mathrm{O}_{3}$ particles, showing the distribution of the rooted structure in the bulk. The black arrow shows one of the exposures of the rooted structure. (c) High-magnification SEM image of the rooted structure shown in (b). (d) High-magnification HAADF STEM- (left) and elemental mapping images (right) of the rooted structure. The redand green areas in the mapping image correspond to the $\mathrm{Ni}$ - and $\mathrm{Y}_{2} \mathrm{O}_{3}$ phases, respectively. 
a

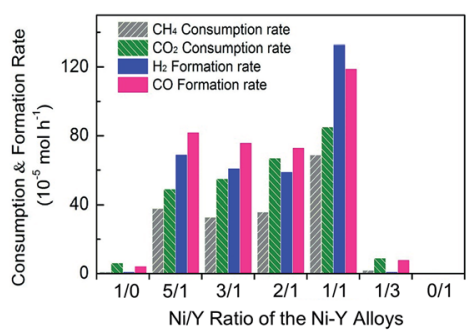

b
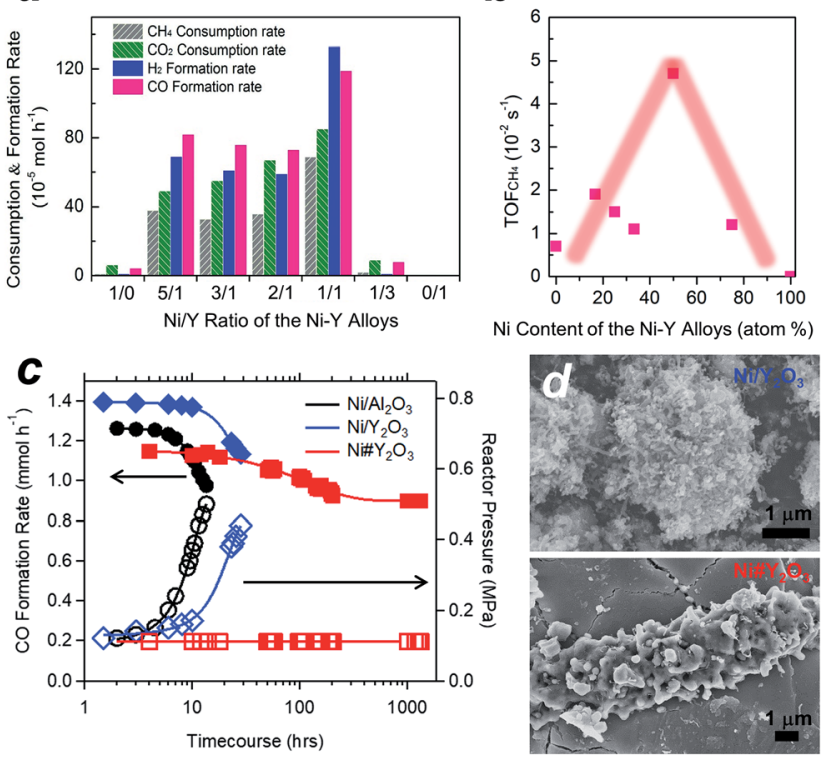

Fig. 3 LT-DRM performance of the $\mathrm{Ni \# Y}_{2} \mathrm{O}_{3}$ - and other $\mathrm{Ni}$-based catalysts. Catalyst amount $=0.1 \mathrm{~g}$; reaction temperature $=723 \mathrm{~K} ; \mathrm{CH}_{4} /$ $\mathrm{CO}_{2} / \mathrm{Ar}=1 / 1 / 98$ in vol\%; flow rate $=100 \mathrm{~mL} \mathrm{~min}{ }^{-1}$. (a) $\mathrm{CO}-/ \mathrm{H}_{2}$ formation rates and $\mathrm{CH}_{4}-/ \mathrm{CO}_{2}$ consumption rates for the $\mathrm{Ni}-\mathrm{Y}_{2} \mathrm{O}_{3}$ composites with different $\mathrm{Y}$ contents. The $\mathrm{Ni \# Y}_{2} \mathrm{O}_{3}$ corresponds to the $\mathrm{Ni} / \mathrm{Y}$ ratio of the $\mathrm{Ni}-\mathrm{Y}$ alloy $=1 / 1$. (b) The turn-over frequencies (TOFs) towards $\mathrm{CH}_{4}$ conversion over the $\mathrm{Ni}-\mathrm{Y}_{2} \mathrm{O}_{3}$ composites with different $\mathrm{Y}$ contents. The $\mathrm{Ni}_{2} \mathrm{Y}_{2} \mathrm{O}_{3}$ corresponds to the $\mathrm{Ni}$ content of the $\mathrm{Ni}-\mathrm{Y}$ alloy $=50 \%$. (c) CO formation (left axis) and reactor pressure (right axis) for the $\mathrm{Ni \# Y}_{2} \mathrm{O}_{3}$ - and supported Ni catalysts. (d) SEM images of the $\mathrm{Ni}$ / $\mathrm{Y}_{2} \mathrm{O}_{3}-$ and $\mathrm{Ni}_{2} \mathrm{Y}_{2} \mathrm{O}_{3}$ catalysts, $6 \mathrm{~h}$ after subjected to the LT-DRM atmosphere.

catalyst exhibited a much higher $\mathrm{TOF}_{\mathrm{CH}_{4}}$ than the other catalysts prepared from different alloy precursors (Fig. 3b). The $\mathrm{Ni} \# \mathrm{Y}_{2} \mathrm{O}_{3}$ catalyst was optimized in terms of composition to achieve the highest LT-DRM performance.

We finally compared the $\mathrm{Ni} \# \mathrm{Y}_{2} \mathrm{O}_{3}$ catalyst with traditional supported catalysts in terms of long-term stability for LT-DRM (Fig. 3c). Note that the size of the Ni sites of $\mathrm{Ni} \mathrm{Y}_{2} \mathrm{O}_{3}(19 \mathrm{~nm})$ was close to those of the supported catalysts including $\mathrm{Ni} / \mathrm{Y}_{2} \mathrm{O}_{3}$ $(19 \mathrm{~nm})$ and $\mathrm{Ni} / \mathrm{Al}_{2} \mathrm{O}_{3}(22 \mathrm{~nm})$ (Table $\mathrm{S} 1$ and Fig. $\left.\mathrm{S} 10 \dagger\right)$. However, the $\mathrm{NiH} \mathrm{Y}_{2} \mathrm{O}_{3}$ catalyst stably promoted LT-DRM at $723 \mathrm{~K}$ for over 1000 hours, keeping the reactor pressure constant. A slight drop during the first 100 hours was observed, likely because the catalyst needed an initiation to reach a balance of carbon deposition and re-oxidation. In contrast, the traditional supported catalysts such as $\mathrm{Ni} / \mathrm{Al}_{2} \mathrm{O}_{3}$ and $\mathrm{Ni} / \mathrm{Y}_{2} \mathrm{O}_{3}$ showed rapid lowering in $\mathrm{CO}$ formation although they exhibited superior catalytic activity in the early stages.

A similar trend was also observed in dense gas conditions (Fig. S11; $\dagger$ catalyst amount $=0.1 \mathrm{~g}$; reaction temperature $=823$ $\mathrm{K} ; \mathrm{CH}_{4} / \mathrm{CO}_{2} / \mathrm{N}_{2}=10 / 10 / 5 \mathrm{in}$ vol\%; flow rate $=25 \mathrm{~mL} \mathrm{~min}^{-1}$ ). The initial $\mathrm{CH}_{4}$ - and $\mathrm{CO}_{2}$ conversions in LT-DRM were $49 \%$ and $38 \%$ over the supported $\mathrm{Ni} / \mathrm{Al}_{2} \mathrm{O}_{3}$ catalyst, respectively, but rapidly decreased down to $12 \%$ and $9.1 \%$ after $10 \mathrm{~h}$. However, our $\mathrm{Ni}_{2} \mathrm{Y}_{2} \mathrm{O}_{3}$ catalyst initially exhibited $12 \%$ and $20 \%$ for the

$\mathrm{CH}_{4}{ }^{-}$and $\mathrm{CO}_{2}$ conversions, respectively, and kept them higher than $7.5 \%$ and $14 \%$ even at a time course of $100 \mathrm{~h}$. The reactor pressure containing the supported catalysts increased as the conversion rates decreased, which was a typical trend observed when the reactor is clogged by carbon deposits (Fig. 3c and the inset in Fig. S11 $†$ ). In addition, a higher $\mathrm{TOF}_{\mathrm{CH}_{4}}$ was exhibited by the supported catalysts (Table $\mathrm{S} 2 \dagger$ ), but the carbon balance was much larger than unity $\left(i . e\right.$. $\left[\mathrm{CH}_{4}\right.$ consumption rate $+\mathrm{CO}_{2}$ consumption rate]/CO formation rate $>1.0$; see Table $\mathrm{S} 3 \dagger$ and the caption). The provided carbon species of $\mathrm{CH}_{4}$ and/or $\mathrm{CO}_{2}$ were more readily converted into carbon deposits than $\mathrm{CO}$ over the supported catalysts. Unlike the supported catalysts, $\mathrm{Ni} \mathrm{Y}_{2} \mathrm{O}_{3}$ exhibited a unity of carbon balance to achieve full conversion of $\mathrm{CH}_{4}$ and $\mathrm{CO}_{2}$ into $\mathrm{CO}$ without carbon deposits.

In order to elucidate the origin of the carbon-deposition tolerance of $\mathrm{Ni}_{2} \mathrm{Y}_{2} \mathrm{O}_{3}$, we performed different characterizations of the catalysts that were exposed to the LT-DRM atmosphere for $6 \mathrm{~h}$ (see Fig. S12† for pXRD). SEM observation showed that the supported $\mathrm{Ni} / \mathrm{Al}_{2} \mathrm{O}_{3}$ as well as $\mathrm{Ni} / \mathrm{Y}_{2} \mathrm{O}_{3}$ were heavily covered with fibrous deposits (Fig. $3 \mathrm{~d}$ and $\mathrm{S} 13 \dagger$ ). The $\mathrm{Ni} \# \mathrm{Y}_{2} \mathrm{O}_{3}$ catalyst was free from fibrous deposits, instead it was thinly coated with a deposit layer (Fig. 3d and S14†). Raman analyses demonstrated that this deposited layer consisted of disordered and deficient carbon species (Fig. S15 and Table S4†). ${ }^{33,34}$ In addition, hard X-ray photoemission spectroscopy (HAXPES: Fig. S16 $\dagger$ ) and thermogravimetry (TG: Fig. S17 $\dagger$ ) showed that the total amount of carbon deposits on the $\mathrm{Ni} \mathrm{Y}_{2} \mathrm{O}_{3}$ catalyst was less than that on the $\mathrm{Ni} / \mathrm{Al}_{2} \mathrm{O}_{3}-$ or $\mathrm{Ni} / \mathrm{Y}_{2} \mathrm{O}_{3}$ catalysts.

We then conducted in situ TEM to shed light on the growth dynamics of the fibrous carbon in the LT-DRM atmosphere. The $\mathrm{Ni} / \mathrm{Al}_{2} \mathrm{O}_{3}$ catalyst was exposed to a reactant gas consisting of equimolar $\mathrm{CH}_{4}$ and $\mathrm{CO}_{2}$ at $723 \mathrm{~K}$ with a pressure of $200 \mathrm{~Pa}$, and observed with high-voltage in situ TEM (JEM-1000K RS TEM (JEOL), Nagoya Univ.). In an aliquot taken $2 \mathrm{~h}$ after the exposure to the reactant gas, an onion-shell pattern from graphitic carbon was clearly recognized all the way around the supported Ni nanoparticles (Fig. 4a). A series of in situ TEM snapshots

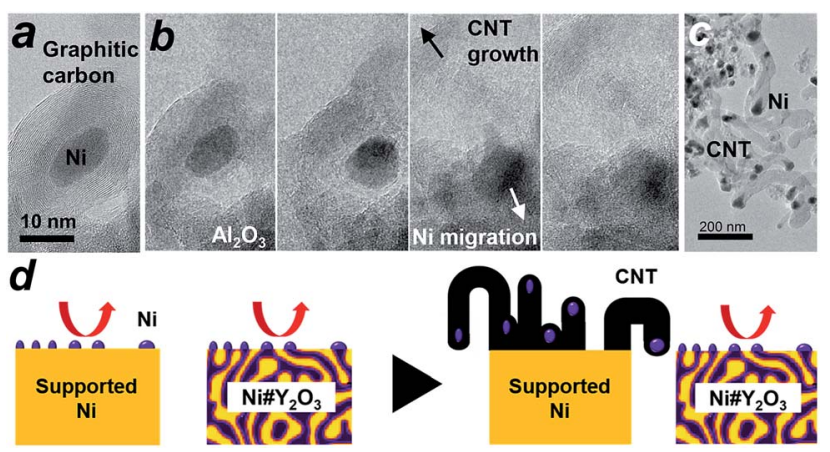

Fig. 4 Dynamic TEM observations of carbon deposition. (a and b) In situ TEM images visualizing the growth of fibrous carbon deposits (carbon nanotubes: CNT) over the $\mathrm{Ni} / \mathrm{Al}_{2} \mathrm{O}_{3}$ catalyst in the LT-DRM atmosphere. Snapshots of the CNT growth. Shooting interval: $\sim 2$ seconds. (c) TEM image of the $\mathrm{Ni} / \mathrm{Al}_{2} \mathrm{O}_{3}$ catalyst taken after subjection to LT-DRM for $6 \mathrm{~h}$. (d) A model for the inhibited CNT growth over the

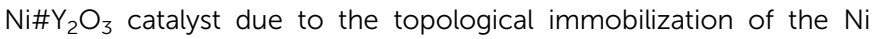
catalysis centre. 
show that this graphitic carbon layer was decomposed near at the $\mathrm{Ni} / \mathrm{Al}_{2} \mathrm{O}_{3}$ interface, most likely by oxygen species donated from the $\mathrm{Al}_{2} \mathrm{O}_{3}$ support (Fig. $4 \mathrm{~b}$, see Movie $\mathrm{S} 1 \dagger$ ). The Ni nanoparticle in the field of view migrated away from the center to the bottom right through the missing part of the graphitic carbon layer.

Fig. 4b also shows that a rapid growth of hollow, multiwalled carbon nanotubes (CNT) was triggered by the migration of $\mathrm{Ni}$ nanoparticles. It is acknowledged that $\mathrm{Ni}$ nanoparticles, when they are able to freely migrate around without a support, play the role of an efficient catalyst that promotes the growth of long-length CNT fibres from gaseous carbon species such as ethanol vapour via a vapour-solid (VS) mechanism. ${ }^{35-37}$ The carbon species provided from the gaseous atmosphere are dissolved in the Ni bulk and recrystallize on the surface in the form of a CNT, which further grows along with the drift of the migrating nanoparticles. As a result of collective migration of the $\mathrm{Ni}$ nanoparticles, the $\mathrm{Ni} / \mathrm{Al}_{2} \mathrm{O}_{3}$ and $\mathrm{Ni} / \mathrm{Y}_{2} \mathrm{O}_{3}$ catalysts were densely covered with large numbers of CNTs $(50 \mathrm{~nm}$ and $500 \mathrm{~nm}$ in average thickness and length, respectively; Fig. 4c, $\mathrm{S} 13$ and S18 $\dagger$ ) after exposure to the LT-DRM atmosphere for $6 \mathrm{~h}$. Note that each of the grown CNT contained one Ni nanoparticle at one end as the growth front.

By contrast to the supported Ni nanoparticles, the Ni catalyst centre of $\mathrm{Ni} \# \mathrm{Y}_{2} \mathrm{O}_{3}$ is topologically immobilized due to entanglement with its $\mathrm{Y}_{2} \mathrm{O}_{3}$ counterpart, which can preclude particle migration and the accompanying CNT growth (Fig. 4d, see Fig. S19†). Moreover, the HAXPES results on the Ni 2p and $\mathrm{O} 1 \mathrm{~s}$ regions showed that the $\mathrm{Ni}$ phase of $\mathrm{Ni} \mathrm{Y}_{2} \mathrm{O}_{3}$ was retained as metal in the LT-DRM atmosphere, whereas the Ni phase of $\mathrm{Ni}$ / $\mathrm{Y}_{2} \mathrm{O}_{3}$ or $\mathrm{Ni} / \mathrm{Al}_{2} \mathrm{O}_{3}$ was oxidized and/or carburized by $\mathrm{CO}_{2}$ and/or $\mathrm{CH}_{4}$ (Fig. S20 and S21 $\dagger$ ). The HAXPES spectra in the $\mathrm{Y} 3 \mathrm{~d}$ region demonstrated that the $\mathrm{Y}_{2} \mathrm{O}_{3}$ phase of $\mathrm{Ni}_{2} \mathrm{Y}_{2} \mathrm{O}_{3}$, unlike that of $\mathrm{Ni}$ / $\mathrm{Y}_{2} \mathrm{O}_{3}$, contained abundant oxygen vacancies (Fig. S22 and $\mathrm{S} 23 \dagger){ }^{38-40}$ The oxygen-deficient $\mathrm{Y}_{2} \mathrm{O}_{3}$ of $\mathrm{Ni} \# \mathrm{Y}_{2} \mathrm{O}_{3}$ not only topologically immobilizes the $\mathrm{Ni}$ catalysis centre, but also may contribute to the elimination of carbon deposits via atomic exchange at the $\mathrm{Ni}-\mathrm{Y}_{2} \mathrm{O}_{3}$ interface. In addition, the carbon deposits formed on the catalysis centre of $\mathrm{Ni} \# \mathrm{Y}_{2} \mathrm{O}_{3}$ can be more readily oxidized than $\mathrm{CNT}$ or graphitic carbon because of their disordered and deficient nature (Fig. S15 and Table S4†). ${ }^{\mathbf{1 4 1}}$ Therefore, the rooted $\mathrm{Ni} \# \mathrm{Y}_{2} \mathrm{O}_{3}$ catalyst, due to its topological advantages and the synergistic function with the oxygendeficient $\mathrm{Y}_{2} \mathrm{O}_{3}$, successfully inhibited carbon deposition and improved reaction stability.

\section{Conclusions}

In conclusion, we present a catalyst design strategy that involves alloy preparations coupled with atmospheric processing to promote the spontaneous formation of nanocomposites consisting of entangled networks of metal and oxides. By tuning the composition of alloy precursors and the processing atmosphere, we have successfully built a composite catalyst with a rooted nanostructure, namely, $\mathrm{Ni} \# \mathrm{Y}_{2} \mathrm{O}_{3}$. The $\mathrm{Ni} \# \mathrm{Y}_{2} \mathrm{O}_{3}$ catalyst realized an improved activity and long-term stability to LTDRM. In situ microscopic observations demonstrated that the carbon deposition occurring on traditional supported catalysts is attributable to the collective migration of metal nanoparticles. The catalysis centre of the $\mathrm{Ni}_{2} \mathrm{Y}_{2} \mathrm{O}_{3}$ is topologically immobilized by its oxygen-deficient $\mathrm{Y}_{2} \mathrm{O}_{3}$ counterpart to preclude particle migration and inhibit carbon deposition. Finally, the material design strategy of rooted catalysts reported here is not limited to the specific conversion of methane, but can be used for a broad range of practical applications, in which stable yet active metal/non-metal interfaces play a central role in performance, such as electrode catalysts for fuel cells and/or secondary batteries. ${ }^{\mathbf{4 2 , 4 3}}$

\section{Conflicts of interest}

There are no conflicts to declare.

\section{Acknowledgements}

This work was preliminarily supported by the JST CREST program (grant No. JPMJCR15P1) and the JST PRESTO program towards "Innovative Catalysts". We acknowledge support from the Advanced Characterization Nanotechnology Platform of the High Voltage Electron Microscope Laboratory of Nagoya University. This work was carried out by utilizing the facility of NIMS TEM Station and was supported by the Global Research Center for Environment and Energy based on Nanomaterials Science. The HAXPES measurements were performed under the approval of the NIMS Synchrotron X-ray Station (Proposal No. 2015B4605, 2016A4607, 2016B4600, 2017A4602, 2017B4605, 2018A4600). The authors wish to thank Dr Iida, Mr Takeda and Ms Nohara for their persistent assistance and/or fruitful discussions to accomplish this work.

\section{Notes and references}

1 D. Pakhare and J. Spivey, Chem. Soc. Rev., 2014, 43, 78137837.

2 L. Shi, G. H. Yang, K. Tao, Y. Yoneyama, Y. S. Tan and N. Tsubaki, Acc. Chem. Res., 2013, 46, 1838-1847.

3 S. Li and J. Gong, Chem. Soc. Rev., 2014, 43, 7245-7256.

4 J. W. Han, C. Kim, J. S. Park and H. Lee, ChemSusChem, 2014, 7, 451-456.

5 D. San-José-Alonso, J. Juan-Juan, M. J. Illán-Gómez and M. C. Román-Martínez, Appl. Catal., A, 2009, 371, 54-59.

6 M.-S. Fan, A. Z. Abdullah and S. Bhatia, Appl. Catal., B, 2010, 100, 365-377.

7 J. R. Rostrupnielsen and J. B. Hansen, J. Catal., 1993, 144, 3849.

8 S. Wang, G. Q. Lu and G. J. Millar, Energy Fuels, 1996, 10, 896-904.

9 A. M. Gadalla and B. Bower, Chem. Eng. Sci., 1988, 43, 30493062 .

10 S. C. Tsang, J. B. Claridge and M. L. H. Green, Catal. Today, 1995, 23, 3-15.

11 A. W. Budiman, S. H. Song, T. S. Chang, C. H. Shin and M. J. Choi, Catal. Surv. Asia, 2012, 16, 183-197.

12 S. M. Kim, P. M. Abdala, T. Margossian, D. Hosseini, L. Foppa, A. Armutlulu, W. V. Beek, A. Comas-Vives, 
C. Copéret and C. R. Müller, J. Am. Chem. Soc., 2017, 139, 1937-1949.

13 T. Margossian, K. Larmier, S. M. Kim, F. Krumeich, A. Fedorov, P. Chen, C. R. Müller and C. Copéret, J. Am. Chem. Soc., 2017, 139, 6919-6927.

14 Z. Liu, D. C. Grinter, P. G. Lustemberg, T. D. Nguyen-Phan, Y. Zhou, S. Luo, I. Waluyo, E. J. Crumlin, D. J. Stacchiola, J. Zhou, J. C. Carrasco, H. B. Busnengo, M. V. GandugliaPirovano, S. D. Senanayake and J. A. Rodriguez, Angew. Chem., Int. Ed., 2016, 55, 7455-7459.

15 Y. H. Hu and E. Ruckenstein, Adv. Catal., 2004, 48, 297-345. 16 Y. H. Hu and E. Ruckenstein, Catal. Rev., 2002, 44, 423-453. 17 D. Pakhare, C. Shaw, D. Haynes, D. Shekhawat and J. Spivey, J. $\mathrm{CO}_{2}$ Util., 2013, 1, 37-42.

18 Y. Kathiraser, U. Oemar, E. T. Saw, Z. Li and S. Kawi, Chem. Eng. J., 2015, 278, 62-78.

19 S. Das, J. Ashok, Z. Bian, N. Dewangan, M. H. Wai, Y. Du, A. Borgna, K. Hidajat and S. Kawi, Appl. Catal., B, 2018, 230, 220-236.

20 Y. Kathiraser, W. Thitsartarn, K. Sutthiumporn and S. Kawi, J. Phys. Chem. C, 2013, 117, 8120-8130.

21 Z. Li, M. Li, Z. Bian, Y. Kathiraser and S. Kawi, Appl. Catal., B, 2016, 188, 324-341.

22 Z. Li, S. Das, P. Hongmanorom, N. Dewangan, M. H. Wai and S. Kawi, Catal. Sci. Technol., 2018, 8, 2763-2778.

23 Z. Li and S. Kawi, Catal. Sci. Technol., 2018, 8, 1915-1922.

24 Z. Li, Z. Wang, B. Jiang and S. Kawi, Catal. Sci. Technol., 2018, 8, 3363-3371.

25 Z. Li, Y. Kathiraser and S. Kawi, ChemCatChem, 2015, 7, 160168.

26 Z. Li, Y. Kathiraser, J. Ashok, U. Oemar and S. Kawi, Langmuir, 2014, 30, 14694-14705.

27 Z. Li, L. Mo, Y. Kathiraser and S. Kawi, ACS Catal., 2014, 4, 1526-1536.
28 Z. Li, B. Jiang, Z. Wang and S. Kawi, J. CO2 Util., 2018, 27, 238-246.

29 Z. Li and S. Kawi, ChemCatChem, 2018, 10, 2994-3001.

30 T. Tanabe, T. Imai, T. Tokunaga, S. Arai, Y. Yamamoto, S. Ueda, G. V. Ramesh, S. Nagao, H. Hirata, S. Matsumoto, T. Fujita and H. Abe, Chem. Sci., 2017, 8, 3374-3378.

31 M. F. Mark and W. F. Maier, J. Catal., 1996, 164, 122-130.

32 G. L. Bezemer, J. H. Bitter, H. P. Kuipers, H. Oosterbeek, J. E. Holewijn, X. D. Xu, F. Kapteijn, A. Jos van Dillen and K. P. de Jong, J. Am. Chem. Soc., 2006, 128, 3956-3964.

33 A. C. Ferrari and J. Robertson, Phys. Rev. B: Condens. Matter Mater. Phys., 2000, 61, 14095-14107.

34 M. A. Pimenta, G. Dresselhaus, M. S. Dresselhaus, L. G. Cancado, A. Jorio and R. Saito, Phys. Chem. Chem. Phys., 2007, 9, 1276-1290.

35 R. T. K. Baker, M. A. Barber, P. S. Harris, F. S. Feates and R. J. Waite, J. Catal., 1972, 26, 51-62.

36 R. T. Yang and J. P. Chen, J. Catal., 1989, 115, 52-64.

37 J.-P. Tessonnier and D. S. Su, ChemSusChem, 2011, 4, 824847.

38 G. B. Sun, K. Hidajat, X. S. Wu and S. Kawi, Appl. Catal., B, 2008, 81, 303-312.

39 P. Malacrida, H. G. S. Casalongue, F. Masini, S. Kaya, P. Hernández-Fernández, D. Deiana, H. Ogasawara, I. E. L. Stephens, A. Nilsson and I. Chorkendorff, Phys. Chem. Chem. Phys., 2015, 17, 28121-28128.

40 X. Huang, G. Xue, C. Wang, N. Zhao, N. Sun, W. Wei and Y. Sun, Catal. Sci. Technol., 2016, 6, 449-459.

41 P. Ferreira-Aparicio, M. Fernandez-Garcia, A. Guerrero-Ruiz and I. Rodríguez-Ramos, J. Catal., 2000, 190, 296-308.

42 W. Wang, C. Su, Y. Wu, R. Ran and Z. Shao, Chem. Rev., 2013, 113, 8104-8151.

43 M. R. Palacin, Chem. Soc. Rev., 2009, 38, 2565-2575. 